Research, part of a Special Feature on Practicing Panarchy: Assessing Legal Flexibility, Ecological Resilience, and Adaptive Governance in U.S. Regional Water Systems Experiencing Climate Change

\title{
Transforming (perceived) rigidity in environmental law through adaptive governance: a case of Endangered Species Act implementation
}

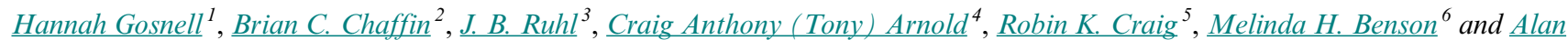 \\ Devenish $^{I}$
}

ABSTRACT. The Endangered Species Act (ESA) is often portrayed as a major source of instability and crisis in river basins of the U. $\mathrm{S}$. West, where the needs of listed fish species frequently clash with agriculture dependent on federal irrigation projects subject to ESA Section 7 prohibitions on federal agency actions likely to jeopardize listed species or adversely modify critical habitat. Scholarship on Section 7 characterizes the process as unwaveringly rigid, the legal "hammer" forcing federal agencies to consider endangered species' needs when proposing operations and management plans for federally funded irrigation. In this paper, we identify barriers to an integrated approach to Section 7 implementation and characterize a set of strategies for overcoming its rigidity that may have broader applicability. We draw on lessons derived from the Klamath Basin along the Oregon-California border, where cross-scale processes and venues involving interagency collaboration among leaders in the U.S. Fish and Wildlife Service, the National Marine Fisheries Service, and the U.S. Bureau of Reclamation supported efforts to replace an ecologically and socially fragmented Upper Basin/Lower Basin approach to ESA implementation fraught with conflict. The result was the nation's first joint biological opinion (BiOp), which effectively institutionalized an adaptive, flexible, integrated approach to water sharing among competing interests. Keys to success included existing collaborative capacity related to shifting stakeholder networks, trust, and relationships and a shift in local agency culture facilitated by empathic leadership leading to a greater sense of shared responsibility for Section 7 compliance. A collaborative hydrologic modeling process enhanced participatory capacity, facilitated transformative social and technical learning, and cultivated greater understanding of the social-ecological system among key stakeholders. The 2013 joint BiOp exemplifies both governmental capacity for flexibility and evolution within the constraints of formal law and the potential for greater integration among federal agencies and between federal agencies and stakeholders involved in ESA implementation.

Key Words: adaptive capacity; biodiversity governance; biological opinion; collaboration; empathy; Endangered Species Act; hydrologic modeling; integrated natural resource management; Klamath Basin; participatory capacity; resilience; Section 7 consultation; trust

\section{INTRODUCTION}

Within the realm of natural resource management- the proving ground for theories of social-ecological system (SES) resilience -it is hard to imagine a better example of system "release" and "reorganization" (Holling 2001) than the almost predictable turbulence regularly caused by implementation of Section 7 of the federal Endangered Species Act (ESA) (16 U.S.C. § 1536). No incident better illustrates that potential than the events surrounding implementation of Section 7 in the Klamath Basin in 2001 (Fig. 1), when the U.S. Fish and Wildlife Service (FWS) and the National Marine Fisheries Service (NMFS) issued separate biological opinions (BiOps) that resulted (pursuant to a federal court opinion) in the U.S. Bureau of Reclamation (BOR) shutting off water to roughly 1200 family farms during a drought, leaving hundreds of thousands of acres of farmland without irrigation and leading to an estimated \$35 million in lost farm income (Jaeger 2004, Doremus and Tarlock 2008). The story of how community members and resource managers navigated subsequent aftershocks and ultimately reorganized over the following decade has been the subject of numerous journal articles, books, and documentaries (e.g., Doremus and Tarlock 2008, Gosnell and Kelly 2010, Chaffin et al. 2014a, Chaffin et al. $2016 a$ ). Although there is debate about the degree to which lasting transformation of the Klamath Basin SES has occurred in the wake of the 2001 crisis (Chaffin et al. 2016b), many agree that there was a significant increase in collaborative capacity during negotiations surrounding the proposed Klamath Basin Restoration Agreement (Gosnell and Kelly 2010, U.S. Department of the Interior 2010, Chaffin et al. 2016a). The improved collaboration aligned in many ways with the principles of adaptive governance, that is, governance institutions that emerge to more flexibly manage SESs for resilience in the face of changing conditions (Folke et al. 2005, Chaffin et al. 2014b).

Contributing to that dynamic was the development of an innovative approach to Section 7 implementation that resulted in the nation's first joint BiOp between FWS and NMFS. Although it addressed only BOR's actions in the basin (which, admittedly, are only part of the problem), and a court has since ordered reinitiation of formal consultation between NMFS, FWS, and BOR (Hoopa Valley Tribe v. National Marine Fisheries Service, 230 F. Supp. 3d 1106 [N.D. Cal. 2017], Yurok Tribe v. Bureau of Reclamation 231 F. Supp. 3d 450 [N.D. Cal. 2017]), the 2013 joint $\mathrm{BiOp}$ stands as a model of integrated natural resource management and provides evidence that, under the right conditions, collaborative strategies aimed at enhancing adaptive capacity can overcome many of the constraints associated with

\footnotetext{
${ }^{1}$ College of Earth, Ocean, and Atmospheric Sciences, Oregon State University, Corvallis, OR, USA, ${ }^{2}$ W.A. Franke College of Forestry \& Conservation, University of Montana, Missoula, MT, USA, ${ }^{3}$ Vanderbilt University Law School, Nashville, TN, USA, ${ }^{4}$ Brandeis School of Law, Department of Urban and Public Affairs, Center for Land Use and Environmental Responsibility, University of Louisville, Louisville, KY, USA, ${ }^{5}$ S. J. Quinney College of Law, Global Change \& Sustainability Center, University of Utah, Salt Lake City, UT, USA, ${ }^{6}$ Haub School of Environment and Natural Resources, University of Wyoming, Laramie, WY, USA
} 
Fig. 1. Map of the Klamath Basin.

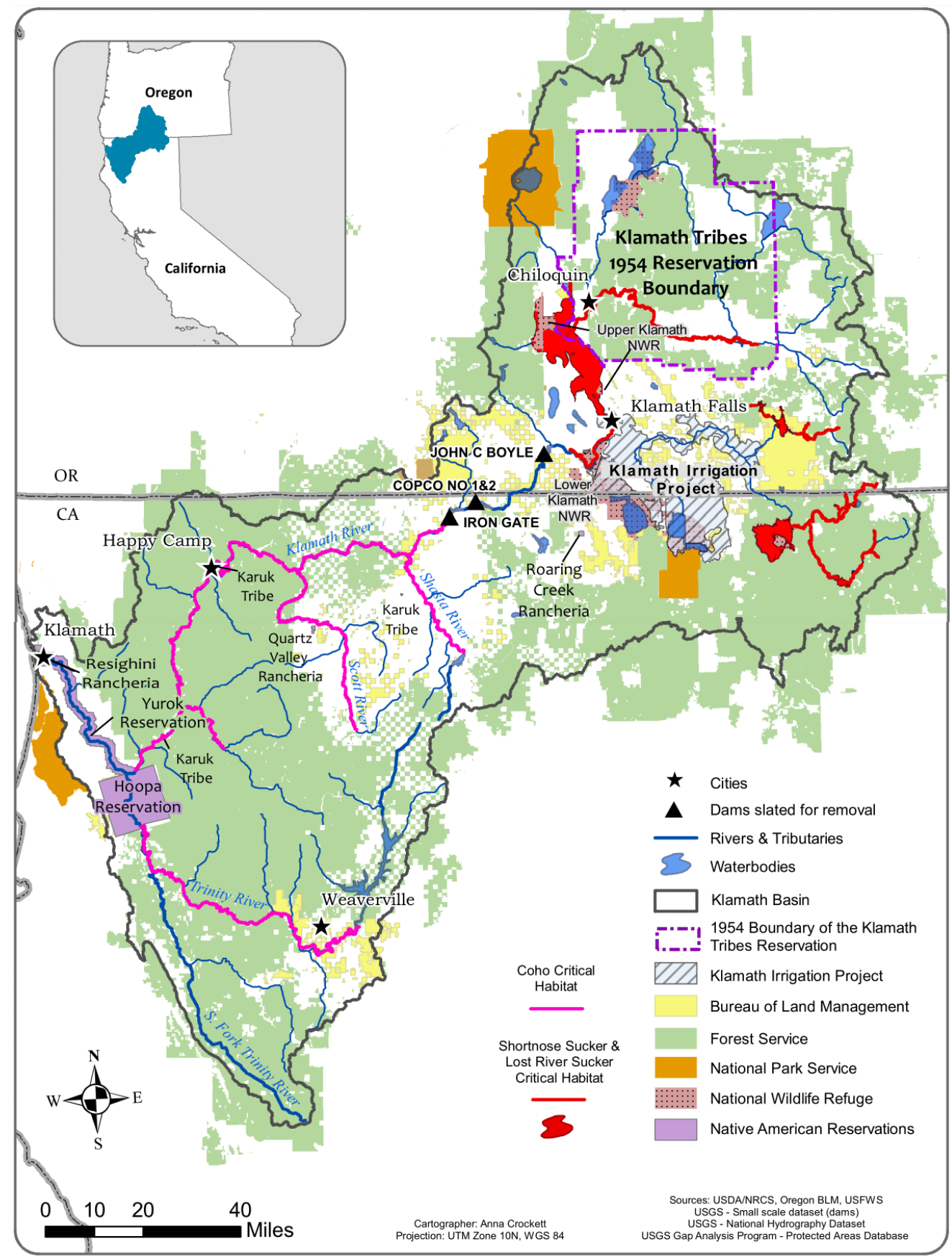

the Section 7 consultation process. We seek to characterize the governance conditions that influenced and led to this novel, although temporary, outcome in the Klamath Basin. Focusing on the important role that federal agencies played in better aligning Section 7 implementation in the Klamath with principles of adaptive governance and resilience-based ecosystem stewardship (Chapin et al. 2009), we identify general principles and strategies that potentially could be used in other contested bioregional management contexts subject to Section 7 and similar federal and state programs. We also consider limitations associated with Section 7's arguably myopic focus on federal actions, which challenge bioregional conservation efforts.

The ESA is comprehensive legislation for the preservation of endangered species and has long been one of the most powerful environmental laws in the United States (Sax and Keiter 2006). It plays an important role in the management of river basins throughout the USA (Benson 2012, Craig 2014). This is especially true in the arid West, where the needs of ESA-listed (endangered 
or threatened) fish species frequently clash with agriculture dependent on federally funded irrigation projects subject to Section 7 of the Act. Section 7 requires federal agencies to "consult" with the FWS or NMFS to ensure that their actions are not likely to jeopardize a listed species or adversely modify its critical habitat. Because the ESA mandates that federal agencies (1) consider only "best available science" (and not socioeconomic factors) when consulting on federal actions that may have an impact on listed species; and (2) reverse the trend toward extinction "whatever the cost" (TVA v. Hill, 437 U.S. 153 [1978]), implementation of the ESA often triggers social and economic crisis by limiting how humans may use resources that species also need (Cosens et al. 2017). The Act is disliked and often feared because it exposes underlying tensions between development and the environment in courtrooms, news media, and the greater public discourse (Ruhl 2012).

Although the ESA is decidedly species-centric - it commands "listing" of species as endangered or threatened (Section 4), prohibits "take" of endangered and most threatened animal species (Section 9), and prohibits federal agencies from jeopardizing the continued existence of listed species (Section 7) -it recognizes the importance of ecological systems to its species protection mission. For example, one of the criteria for listing of a species is "the present or threatened destruction, modification, or curtailment of its habitat or range" (Section 4(a)(1), and "critical habitat" is defined to mean areas "on which are found those physical or biological features ... essential to the conservation of the species" (Section 3(5)). Moreover, Congress made clear that the purpose of the ESA is "to provide a means whereby the ecosystems upon which endangered species and threatened species depend may be conserved" (Section 2(b)). The Section 7 consultation process, though ultimately focused on the status of a species, thus allows for, and in fact requires, consideration of broader ecological conditions.

Through the lens of SES resilience (Folke 2006) and adaptive governance (Folke et al. 2005), the Section 7 consultation process can be thought of as a legal intervention aimed at identifying species-centric thresholds, i.e., jeopardy, that, when crossed, signal ecological crisis associated with a high risk of species extinction. As one of the few major environmental laws explicitly committed to identifying and enforcing thresholds associated with biodiversity, the ESA has the potential to play a major role in catalyzing system reorganization and, ideally, the development of more stable and sustainable trajectories. Serving as a canary in the coal mine, an ESA listing or a BiOp can be an important lever of change, forcing society to address resource scarcity issues it may have been avoiding for decades (Saundry 2009).

Because of its role in causing social crisis, however, and in spite of Congress's good intentions, the ESA is generally perceived as rigid, myopic, and incompatible with resilience thinking. It is viewed as a barrier to adaptive governance, incapable of promoting the innovation and creativity necessary for resolving endangered species issues in the context of SESs associated with working landscapes (Benson 2012, Gunderson 2013, Gunderson et al. 2014). Scholars have noted, however, that crises caused by the implementation of laws like the ESA can eventually lead to positive reorganization through systemic collapse or threat of collapse of SESs followed by transformative change (Folke et al.
2009, Olsson et al. 2006, Moore et al. 2014, Chaffin et al. 2016b). Cosens et al. (2017) observed that top-down regulations such as the ESA can trigger innovation by presenting only narrow solutions that are socially and/or economically unacceptable. Others have noted that even the threat of the "hammer" of governmental intervention associated with the ESA can act as a catalyst and alter watershed and basin social dynamics by incentivizing collaboration among resource users and land managers to prevent further regulation (Prokopy et al. 2014). The latter point is consistent with theories that disruptive legal actions can actually lead to collaboration, more equitable resource reallocation, and flexible resource management by first destabilizing rigid power relationships that exploit both resources and marginalized peoples (Arnold 2004, Karkkainen 2008).

Although there are some success stories related to implementing statutes like the ESA, there is a growing need to identify tools for strategically integrating statutory goals into broader SES governance, addressing legitimate concerns about community socioeconomic stability related to operation of federal water projects, and minimizing social-ecological conflict through deliberate SES transformation (Moore et al. 2014). Satisfying this need will involve finding flexibility in the law to allow for socioeconomic considerations while ensuring ecological goals are not compromised; in other words, flexibility and adaptability are needed against a backdrop of stability for both water users and listed species (Craig et al. 2017). Climate change and associated drought and habitat loss will only exacerbate the need for new approaches (Benson 2012).

In this paper, we dissect the Section 7 consultation process to illustrate the potential for collaborative strategies to overcome legal roadblocks to SES management dynamics. We argue that, aside from its role as a catalyst for change based on crisis, fear, and instability, Section 7 consultation has the potential to serve as a forum for learning, strategic reorganization, and stimulating adaptive governance. Using the history of ESA implementation in the Klamath Basin as a case study, we compare two different approaches to implementing Section 7 and identify the social conditions and strategies that allowed the consultation process to serve as a powerful tool to help facilitate a more adaptive approach to river basin governance. We first provide an overview of the consultation process under Section 7 of the ESA, highlighting the ways in which it tends to undermine resilience, adaptive governance, and an integrated approach to resource management. Then, drawing from qualitative social science research ongoing in the Klamath River Basin since 2008, including document analysis and fieldwork involving over 100 semistructured interviews with stakeholders and key informants associated with efforts to resolve conflict over water, agriculture, tribal rights, and endangered species, we contrast (1) the Upper Basin/Lower Basin approach to Section 7 consultation on listed Lost River and shortnose sucker fishes (Deltistes luxatus and Chasmistes brevirostris) and coho salmon (Oncorhynchus kisutch) species taken by the BOR, NMFS, and FWS in the early 2000s, which resulted in "rotating crises" (Gosnell and Kelly 2010) for irrigators, tribes, and fishermen; with (2) the more integrated approach adopted in 2010 that culminated in the 2013 joint $\mathrm{BiOp}$. In the latter approach, we highlight the importance of interagency cooperation during consultation, the use of hydrologic modeling to better understand the whole system, and the engagement of stakeholders in the search for innovative solutions. 
We then identify key factors enabling this shift in approach, including new cross-scale dynamics featuring trust and empathy and the emergence of a forum for learning and coproduction of knowledge around water sharing led by a unique coalition of stakeholders that included prominent leaders from irrigation groups and basin tribes. We further research on resilience and adaptive governance by discussing the ways in which these enabling factors, interagency collaboration, empathic leadership, and transformational learning about the SES, contributed to an expanded sense of place, an extended sphere of concern, and shared ownership of the problem among both stakeholders and federal agency employees, which facilitated a more integrated approach to managing SES dynamics. We also consider how increased attention to the needs of ESA-listed species beyond the federally funded Klamath Irrigation Project would facilitate an even more integrated approach. We conclude with a set of practical lessons for implementing the ESA to promote adaptive governance.

\section{SECTION 7 CONSULTATION AND THE CHALLENGE OF INTEGRATED ADAPTIVE GOVERNANCE}

Although the Section 7 consultation process is well-established, few have fully considered the ways in which the governance structure and process associated with interagency consultation tend to challenge SES resilience, social-economic stability, and the potential for adaptive governance. We build on Benson's (2012) more general assessment of the ESA, which argues that the law contradicts resilience-based governance, i.e., adaptive governance, by promoting fragmented natural resource management that focuses on single species rather than system dynamics and seeks to optimize parts of the system rather than fostering adaptive capacity and resilience throughout the SES. Benson (2012) argues for "a more integrated approach to governance that includes a willingness to reassess demands placed on ecological systems by our social systems." Inattention to such principles of integrated natural resource management is perhaps the most common criticism of the ESA (e.g., Gunderson 2013).

An integrated, problem-solving approach increases capacity for learning and adaptation in the conservation planning process and is an important aspect of adaptive governance (Benson 2012, Carpenter and Brock 2008, Pahl-Wostl 2009, Grantham et al. 2010, Pahl-Wostl et al. 2013, Cosens et al. 2017). Law and resilience scholars describe integration in the law as "mutual cognizance and legal authority for coordination across all governance institutions that influence environmental management and regulation of physically connected resources" (Cosens et al. 2017). One way law can facilitate adaptive governance is through interagency cooperation and coordination aimed at creative problem-solving when confronted with governance problems with cross-agency and cross-scale dimensions. Integrated resource management and interagency cooperation can also create opportunities to engage diverse stakeholders meaningfully in decision making (Arnold et al. 2014, Arnold 2015). We suggest that many of the problematic aspects of ESA Section 7 consultation have more to do with lack of integration among federal agencies implementing the law and poor relations with stakeholders than with the law itself, and that the degree to which the ESA promotes or inhibits adaptive governance is largely contingent on interagency dynamics as well as stakeholder-agency dynamics.
Interagency dynamics in Section 7 consultation: navigating silos Section 7, titled "Interagency Cooperation," describes a process through which federal agencies work together to ensure that they are contributing to the mission of protecting and recovering listed species. Nevertheless, actual implementation of Section 7 often occurs in a fragmented way that can result in a reactive, inefficient approach to biodiversity governance.

Section 7 consists of both prohibitory and affirmative obligations, but it is best known for Section 7(a)(2), which requires that each federal agency carrying out a major action (the "action agency" such as the Bureau of Reclamation or U.S. Forest Service) "consult" with FWS and/or NMFS (depending on the majority habitat of the species, FWS for terrestrial species, NMFS for marine and anadromous species) to "insure that any action authorized, funded, or carried out by such agency ... is not likely to jeopardize the continued existence of any endangered species or threatened species or result in the destruction or adverse modification of [critical] habitat." Under this arrangement, as implemented through joint FWS/NMFS regulations, the onus is on the action agency to (1) determine whether listed species are present in the area of its proposed action; and, if so, (2) develop a biological assessment (BA) that describes the proposed action and its anticipated effects on the listed species; and (3) if the action and consulting agency conclude the proposed action is likely to adversely affect a listed species, request formal consultation with FWS or NMFS (collectively "the Services"). The Services then evaluate the $\mathrm{BA}$ and offer a draft $\mathrm{BiOp}$ stating whether the proposed action is likely to cause jeopardy and/or adverse modification of critical habitat. If the draft $\mathrm{BiOp}$ anticipates jeopardy, it will generally include one or more reasonable and prudent alternatives (RPAs), which modify the proposed action to eliminate jeopardy. The development of the RPAs is subject to negotiation between the action agency and the Services, which ultimately issue a final $\mathrm{BiOp}$ determining, in the consulting agency's or agencies' opinion, whether the proposed action can go forward without violating Section 7. Although, technically, the final decision on whether and how to proceed with the proposed action remains with the action agency, BiOps legally are very influential, as the Klamath Basin history demonstrates.

It is important to note that $\mathrm{BiOps}$ really are just opinions, nearly always based on incomplete information about the species and the larger biophysical system, so there is some flexibility and discretion in how the Services seek compliance with Section 7. That flexibility is tempered, however, by the dynamics between action agencies and the Services, as well as by the principle of institutionalized caution ("precautionary principle") and the fact that citizens can challenge BiOps in court.

Consultation can, in some cases, be adversarial and political, characterized by a lack of transparency, information sharing, and dialogue as the action agency tries to get its proposed action approved (Gosnell 2001). We suggest, however, that such conflict is not inherent in the law; that is, differences in agency culture and poor governance, not lack of authority, are mainly to blame for problems with agency coordination.

Another issue of interagency dynamics associated with the Section 7 consultation process that runs counter to integration is in the division of labor between the FWS, in the Department of Interior, and NMFS, in the Department of Commerce. This 
shared responsibility for implementing the Act can be problematic in SESs or geographic contexts where federal actions impact both terrestrial and marine species, e.g., in river basins of the Pacific Northwest with both freshwater and anadromous fish species, because of differences in agency culture and the way the two agencies approach ESA implementation. Generally, FWS and NMFS will issue separate BiOps regarding the same proposed action, each one focused on the needs of "its" species, even when the proposed action affects shared habitat upon which all the listed species depend. In part to avoid the possibility of mutually contradictory advice from the two agencies, the Section 7 Consultation Handbook notes that "coordination between FWS and NMFS is critical to ensure any reasonable and prudent alternatives prescribed by both the Services ... are compatible ... so the action agency can implement both opinions without further consultation" (USFWS and NMFS 1998:2-14). However, the law does not require coordination and integration and thus they are not guaranteed. As a result, FWS and NMFS BiOps on the same proposed action, e.g., implementing a dam or reclamation project, can be at cross purposes and even undermine one another, as has been the case in the Klamath Basin, where anadromous and freshwater fish species have competing needs.

Stakeholder-agency dynamics in Section 7 implementation: tradeoffs between legitimacy and participatory capacity

The ways in which federal agencies interact with stakeholders during Section 7 consultation also can have significant bearing on the potential for integrated adaptive governance. Resilience scholars argue that allowing key stakeholders to participate in decision making enhances social learning, motivation, and compliance with policy and law; lack of participatory capacity, defined as the right and resources of interested persons and groups to have a role in decision making (Huitema et al. 2009), is a barrier to adaptive governance (Chaffin et al. 2014b, Cosens et al. 2017). "Participatory capacity reduces the likelihood of marginalization of portions of society and, in doing so, increases the likelihood that all aspects of a system will be considered in decision-making" (Cosens et al. 2017). Authentic participation plays an important role in adaptive governance because it helps enhance the perception of legitimacy among stakeholders; people look to it for reassurance during difficult or uncertain situations (Armitage et al. 2008). Legitimacy can be obtained through participatory democracy where stakeholders contribute to "feedback, design, decision making, or implementation of governance" (De Caro et al. 2017).

Stakeholder participation in resource management occurs along a theoretical spectrum, from "inform" to "consult" to "involve" to "collaborate" (duToit and Pollard 2008), but collaboration does not ensure authentic participation. Collaboration can perpetuate structural inequalities and actually reduce the participation of marginalized groups in environmental and resource governance (Foster 2002, Shilling et al. 2009). Collaborative processes are more likely to be socially just and truly participatory if they include the empowerment of marginalized communities, inclusive or meaningful processes, the use of diverse participatory methods, and a mix of formal legal tools (e.g., litigation, regulation, enforcement actions) and informal collaborative tools (Larson and Lach 2010, Quick and Feldman 2011, Arnold et al. 2014).
Section 7 takes an alternate approach to seeking legitimacy through legal requirements for science-based decision making in the preparation of a BiOp, and, under the FWS and NMFS joint implementation regulations, is relatively silent about the need for and role of stakeholder input and/or participation during the consultation process. Relying only on best available science for legitimacy arguably conflicts with principles of good governance and theoretically undermines the potential for compatibility between adaptive governance and the ESA by limiting participatory capacity and hindering social and technical learning. It can also lead to an adversarial dynamic, prone to litigation, between federal agencies and stakeholders, which may result in risk avoidance and lack of innovation in the Services' preparation of BiOps. As Benson (2012) observes, "ESA management efforts are often geared towards avoiding lawsuits rather than building resilience," e.g., the motivation behind any effort to engage stakeholders is likely more about avoiding challenges to the final decision than about working on creative solutions.

The Klamath case, introduced below, illustrates the ways in which lack of integration in Section 7 consultation can manifest, both in interagency relations and in stakeholder-agency relations, but also how these dynamics can shift. We suggest that the approach to implementing Section 7 that culminated in the $2013 \mathrm{BiOp}$ in many ways embodies the shifts called for by law and resilience scholars (e.g., Benson 2012, Gunderson 2013, Cosens et al. 2017), as well as demonstrates the ability of the ESA to support rather than undermine SES resilience and adaptive governance.

\section{SECTION 7 IMPLEMENTATION IN THE KLAMATH BASIN, 1988-2008: AN UPPER BASIN/LOWER BASIN APPROACH}

Since development of the federal Klamath Irrigation Project (KIP) in the early 20th century, the BOR has cultivated a strong relationship with its constituents, the farmers associated with the Klamath Water Users Association (KWUA) who use KIP water for irrigation. The ESA listing of two species of sucker fish in the Upper Basin in 1988 forced BOR to begin consulting with FWS on KIP operations (see Table 1 for chronology), and the federal agencies developed a dynamic in which BOR worked with irrigators to develop a proposed action for KIP operations based on the farmers' irrigation needs, and then delivered it along with a BA to the FWS (and later to NMFS when the coho salmon were listed in 1997) in anticipation of $\mathrm{BiOp}(\mathrm{s})$ that would allow it to continue operations as normal.

Prior to 2013, NMFS and FWS issued BiOps separately and in isolation of one another, as illustrated in Figure 2. NMFS represented the needs of salmon and, by extension, the interests of three Lower Basin tribes (Karuk, Yurok, and Hoopa Valley) and commercial fishermen in the development of its BiOps. FWS, in turn, represented the needs of the suckers, and, by extension, the interests of the Klamath Tribes in the development of its BiOps. The Services left it to BOR to address their uncoordinated demands, which generally consisted of minimum Upper Klamath Lake (UKL) levels for the suckers in the Upper Basin and minimum instream flows for salmon in the Lower Basin, two water demands potentially at odds with each other as well as being individually and collectively at odds with farmers' desires to 
Table 1. Chronology of events related to implementation of Section 7 of the Endangered Species Act in the Klamath Basin.

\begin{tabular}{|c|c|}
\hline 1967 & The Lost River sucker (LRS; Deltistes luxatus) is listed as "rare" under the California Endangered Species Act (CESA). \\
\hline 1971 & The Shortnose sucker (SNS; Chasmistes brevirostris) is listed as "rare" under CESA. \\
\hline 1971 & Both sucker species are identified as "species of concern" under CESA. \\
\hline 1986 & $\begin{array}{l}\text { The Klamath Tribes close their subsistence sucker fishery to conserve the species. } \\
\text { Hundreds of adult suckers die during the summer months in Upper Klamath Lake (UKL). }\end{array}$ \\
\hline 1988 & The U.S. Fish and Wildlife Service (FWS) lists both sucker species as "endangered" under the federal Endangered Species Act (ESA). \\
\hline 1992 & $\begin{array}{l}\text { The Bureau of Reclamation (BOR) prepares the first Biological Assessment (BA) for the Klamath Irrigation Project (KIP) operations; FWS } \\
\text { issues the first Biological Opinion (BiOp) for the sucker species, imposing minimum lake levels for UKL. }\end{array}$ \\
\hline $1995-1997$ & Thousands of suckers die during the summers in UKL. \\
\hline 1997 & $\begin{array}{l}\text { The National Marine Fisheries Service (NMFS) lists the Southern Oregon/Northern California Coast (SONCC) Evolutionarily Significant Unit } \\
\text { (ESU) of coho salmon (Oncorhynchus kisutch), the Southern Distinct Population Segment (DPS) of green sturgeon (Acipenser medirostris), and } \\
\text { the Southern DPS of eulachon (Thaleichthys pacificus) as "threatened" under the federal ESA. }\end{array}$ \\
\hline 2001 & $\begin{array}{l}\text { BOR prepares a BA for proposed KIP operations. } \\
\text { FWS issues a jeopardy BiOp for the two sucker species. } \\
\text { NMFS issues a jeopardy BiOp for the coho salmon. } \\
\text { BOR limits the volume of water delivered to KIP users to comply with the jeopardy BiOps, leading to social and economic hardship for } \\
\text { irrigators. }\end{array}$ \\
\hline 2002 & $\begin{array}{l}\text { BOR prepares a new BA for KIP operations spanning } 2002-2012 \text { and requests reinitiation of consultation with FWS and NMFS. } \\
\text { Both agencies again issue jeopardy BiOps with reasonable and prudent alternatives (RPAs) that call for reduced water deliveries. } \\
\text { Disregarding the BiOps, and in spite of continued drought, BOR provides full water deliveries to irrigators during summer } 2002 . \\
\text { Curtailed flows in the Lower Basin lead to poor water quality and, in September, more than } 30,000 \text { adult salmonids (primarily unlisted } \\
\text { Chinook, Oncorhynchus tshawytscha) die from a bacterial pathogen (columnaris) associated with low flows and high stream temperatures. } \\
\text { Lawsuits by tribes, environmental organizations, and commercial fishermen result in a federal district court ordering the BOR to reinitiate } \\
\text { consultation with FWS and NMFS. }\end{array}$ \\
\hline 2005 & The coho salmon is listed as "threatened" under the CESA. \\
\hline 2005-2009 & The commercial salmon fishing harvest is closed and/or restricted. \\
\hline 2006 & $\begin{array}{l}\text { Settlement talks associated with the Klamath hydroelectric dam relicensing process morph into an "Extended Caucus" that creates the } \\
\text { foundation for developing the Klamath Basin Restoration Agreement (KBRA) and the Klamath Hydroelectric Settlement Agreement (KHSA) } \\
\text { over the next four years. (See Gosnell and Kelly } 2010 \text { for details regarding the KBRA/KHSA development and the process's influence on tribal/ } \\
\text { irrigator power relations.) }\end{array}$ \\
\hline 2007 & $\begin{array}{l}\text { BOR reinitiates consultation with FWS and NMFS, proposing to change its operations to address concerns with its monthly time-step } \\
\text { approach to managing UKL elevations and downstream flows. } \\
\text { FWS issues a nonjeopardy BiOp for suckers after working with BOR to refine the proposed action for the time period spanning } 2007-2017 \text {. }\end{array}$ \\
\hline 2008 & $\begin{array}{l}\text { NMFS issues a draft jeopardy BiOp for the coho, which conflicts with the FWS's } 2007 \text { nonjeopardy BiOp. } \\
\text { BOR requests that NMFS suspend the finalization of the consultation process and BiOp until further notice. }\end{array}$ \\
\hline 2010 & $\begin{array}{l}\text { BOR requests that NMFS finalize its BiOp for the KIP. } \\
\text { NMFS issues a final jeopardy BiOp regarding the coho for KIP operations from 2010-2018, with an RPA that calls for downstream flows that, } \\
\text { when combined with KIP operations, would result in lower UKL levels than those approved in the } 2007 \text { FWS BiOp. } \\
\text { It becomes apparent that, under certain hydrologic conditions, BOR will be unable to meet the expectations of KIP water users and the two } \\
\text { BiOps, putting the agency in an untenable position. It also becomes apparent that FWS will have to reinitiate consultation to evaluate the effects } \\
\text { of the NMFS RPA on the two sucker species, scrapping much of the work that it had done to develop the } 2007 \text { BiOp. } \\
\text { Regional Directors for the three federal agencies, the BOR's Mid Pacific Regional Director, NMFS' Southwest Regional Administrator, and the } \\
\text { FWS's Pacific Southwest Regional Director, meet with their respective field office managers and direct them to develop a new proposed action } \\
\text { and the nation's first joint BiOp. } \\
\text { Basin stakeholders sign initial drafts of the KBRA and KHSA, which represent the culmination of four years of talks regarding a "whole } \\
\text { basin" approach to social-ecological restoration. }\end{array}$ \\
\hline 2012 & $\begin{array}{l}\text { BOR finalizes a new proposed action based on the results of its hydrologic modeling of the Klamath system, issues a new BA, and requests } \\
\text { formal consultation with FWS and NMFS to develop a joint BiOp. }\end{array}$ \\
\hline 2013 & $\begin{array}{l}\text { FWS and NMFS issue a nonjeopardy joint BiOp. } \\
\text { In March, the Oregon Water Resources Department (OWRD) delivers its Findings of Fact and an Order of Determination in the Klamath } \\
\text { River Basin Adjudication regarding water rights in the Klamath Basin (within the state of Oregon) to the Klamath County Circuit Court. } \\
\text { Adjudication-related proceedings in the Oregon portion of the Klamath Basin had been conducted since 1975, with significant implications for } \\
\text { Klamath Tribes' water rights and feasibility of in-stream flows to support sucker recovery. OWRD's Findings determine that the Klamath } \\
\text { Tribes have the most senior and very large water rights in the system and quantify those rights for the first time. } \\
\text { In June, the Klamath Tribes "call the river" based on their newly quantified and legally enforceable water rights; OWRD enforces call and shuts } \\
\text { off water to off-project farmers and ranchers above the lake and in, around, and above historical reservation lands. BOR, FWS, and four } \\
\text { irrigation districts immediately follow with their own calls on the river, but because of drought conditions, these senior users' demands exceed } \\
\text { the available flows. } \\
\text { In fall, the off-project irrigators, mostly located in the basin headwaters northeast of or above the historic reservation boundary, return to the } \\
\text { negotiating table as a result of the June call on the river by the Klamath Tribes and the subsequent economic hardship suffered by nontribal, } \\
\text { off-project agricultural producers that year. Some of these irrigators are also instrumental leaders in the public opposition to the KBRA and } \\
\text { KHSA that had been voiced since } 2010 \text {. }\end{array}$ \\
\hline 2014 & $\begin{array}{l}\text { In April, the parties sign the Upper Klamath Basin Comprehensive Agreement (UKBCA), bringing off-project irrigators and irrigation back } \\
\text { into the comprehensive basin water settlement agreements. This agreement is combined with the KBRA and KHSA. }\end{array}$ \\
\hline 2015 & $\begin{array}{l}\text { In December, the Klamath Basin Agreements (KBRA, KHSA, UKBCA) expire when the U.S. Congress fails to authorize and fund them } \\
\text { through federal legislation. }\end{array}$ \\
\hline 2016 & $\begin{array}{l}\text { In April, the parties sign the Klamath Power and Facilities Agreement (KPFA) and an amended KHSA at a large public ceremony at the } \\
\text { Klamath River's mouth that includes an appearance by U.S. Secretary of the Interior Sally Jewell. This agreement has very little to do with the } \\
\text { KBRA and basin restoration; instead, it settles the outstanding Federal Energy Regulatory Commission (FERC) process that required the KHP } \\
\text { to be either relicensed or decommissioned and facilities removed. The Agreements authorize the removal of the four mainstem Klamath dams } \\
\text { by } 2020 \text { and do not require congressional authorization or funding. }\end{array}$ \\
\hline
\end{tabular}


In June and July, the Yurok Tribes sue BOR and NMFS for mismanagement of endangered salmon in the Klamath River. A Ceratonova shasta parasite outbreak causes the Yurok to suspend fishing throughout 2016. The disease's prevalence is attributed to unhealthily high concentrations of salmon in the river. The Yurok suit follows the NMFS decision to reduce salmon protections rather than divert water away from the KIP and irrigation.

In February, a federal district court orders a review of the 2013 BiOp to re-evaluate the BOR's operating plan to protect threatened coho salmon in the Lower Klamath Basin (Hoopa Valley Tribe v. National Marine Fisheries Service, 230 F. Supp. 3d 1106 (N.D. Cal. 2017); Yurok Tribe v. Bureau of Reclamation 231 F. Supp. 3d 450 (N.D. Cal. 2017)).

In April and May, the Klamath Tribes call the river ${ }^{\dagger}$ again (as in 2013) because they perceive insufficient water system recharge since the end of the drought.

\begin{abstract}
"Calling the river" is the somewhat colloquial expression for the process by which a senior water rights holder in a prior appropriation state enforces that senior right against more junior rights holders in times of water shortage. The exact process of enforcement varies by state but generally involves notification to a state official of the need to shut down junior appropriators and then notice to juniors and/or physical closure of their diversion structures.
\end{abstract}

withdraw water for irrigation. BOR's task was to develop an annual operating plan for KIP that would meet the needs of farmers reliant on KIP water while acknowledging the constraints of the two BiOps. The poor relationship between the federal agencies was recognized by people in both FWS and NMFS:

Basically I think the feeling was that every agency was out for themselves... and [with BOR] having control of the water, the two agencies [FWS and NMFS] had responsibility for just developing their own BiOps and giving them to [BOR]. There wasn't much of any concern [on the part of NMFS] for the water users for what the impact would be ... or for our fish upstream either ... There was just not that much coordination going on between the agencies and when we did BiOps we basically did them in isolation. (Interview, FWS)

The federal team was also fighting in the basin. We weren't getting along. We were being pitted against each other, just like the stakeholders were. The culture of not trusting, not trying to build a relationship, that's where we were. It was battlegrounds essentially. I had bad relationships with [BOR], bad. Very bad. It was terrible! They're just like, "Consult on this!' It was just nothing like it is today. It's been transformed, that process. (Interview, NMFS)

The lack of coordination also caused intense frustration among the water users:

There's been, in my mind over the years, just an utter lack of coordination amongst Bureau of Reclamation, Fish and Wildlife, and National Marine Fisheries.... Theyjust drive me crazy. The agencies. Our plea has been, or the case we're trying to make is, we're about to fall off the cliff if we don't do something a little different. At least try to get some coordination. (Interview, KWUA)

This dynamic resulted in crisis beginning in 2001 when BOR consulted with FWS and NMFS about its planned operations for KIP. Acting independently, the Services concluded that proposed KIP operations would likely jeopardize the continued existence of both the two sucker species in the Upper Basin and the coho salmon in the Lower Basin. As a result of drought and low inflows to KIP reservoirs during the previous winter and spring, and ESA requirements for minimum lake levels and river flows, BOR was forced to limit the amount of water delivered to irrigators, leading to the abrupt water shutoff, economic crisis, and social upheaval described earlier.
Fig. 2. Section 7 Consultation Process pre-2013: Upper Basin/ Lower Basin Approach. Irrigators worked with Bureau of Reclamation (BOR) to develop a proposed action (PA). BOR delivered PA to U.S. Fish and Wildlife Service (FWS) and National Marine Fisheries Service (NMFS) separately. Lower Basin Tribes and fishermen sought to influence NMFS in development of coho biological opinion (BiOp). Klamath Tribes sought to influence FWS in development of suckers BiOp. FWS delivered suckers BiOp to BOR. NMFS delivered coho BiOp to BOR. Process featured little or no collaboration between BOR and FWS or NMFS in development of PA, and little or no coordination between FWS and NMFS in development of BiOps for BOR.

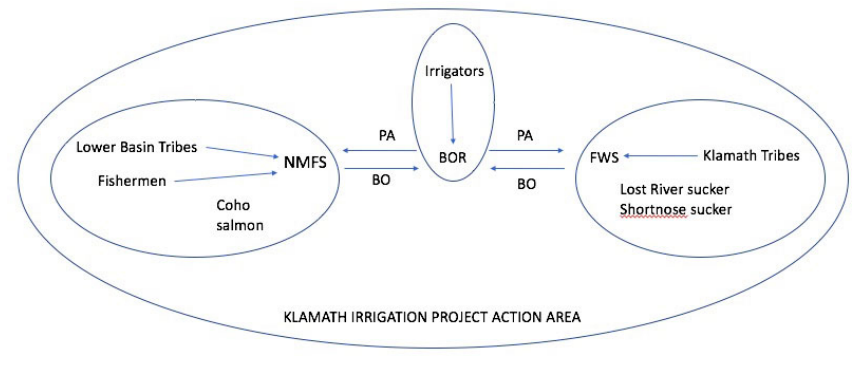

The controversial nature of the FWS and NMFS $2001 \mathrm{BiOps}$ led to a call for external scientific review by a U.S. National Academies of Science/National Research Council (NRC) panel (Doremus and Tarlock 2008, NRC 2004). In February 2002, the Panel released an interim report (NRC 2002) on their assessment of the BiOps and the two 2001 BAs produced by BOR that concluded that there was insufficient scientific and technical information to support the Services' recommendations for higher lake levels (FWS BiOp) and higher Klamath River flows (NMFS $\mathrm{BiOp}$ ) as well as for the BOR's KIP plan.

The BOR read the NRC preliminary report as the "best available science" and responded by releasing a new long-term operation plan (2002-2012) that used the lake level and river flow thresholds applied between 1990 and 2000, thresholds that had been deemed insufficient to protect species in the 2001 BiOps. The BOR adhered to this operation plan during the low precipitation spring and summer of 2002, continuing to deliver water to project farmers. In September 2002, low water flows in the Lower Basin combined with drought conditions created a low oxygen environment ideal for the rapid spread of disease among returning (migrating) fall Chinook salmon (Oncorhynchus tshawytscha; 
CDFG 2004). The California Department of Fish and Game estimated that in just 4 days, over 30,000 Chinook salmon died in the Klamath River below Iron Gate Dam (CDFG 2004). Although this population of Chinook salmon is not protected under the ESA, the species is culturally significant to the Lower Basin tribes and critical to the economic viability of commercial fishing communities along the coast of California, Washington, and Oregon. This abrupt social, ecological, and economic loss effectively relocated the Klamath crisis to the Lower Basin, further revealing the inadequacy of the siloed approach to Section 7 implementation. The 2002 consultation that led to this tragedy and an additional consultation in 2007 (Table 1) made it increasingly clear that the split Upper Basin/Lower Basin approach was untenable. Figure 2 illustrates this "dis-integrated" consultation dynamic, which had a negative effect on the fish, the water users, and other stakeholders in the basin.

Contributing to BOR's water balancing challenge was an outdated approach to operations that relied on uncertain earlyseason runoff forecasts and historical water use to forecast water supply once per month. This approach frequently resulted in forecasts predicting more water than actually became available, leading to BOR releasing too much water early in the season and then experiencing unanticipated shortages later. Irrigators expressed frustration with this approach:

These guys [irrigators] all have to make management
decisions early in the year, right? Are you going to buy
seed, are you planting, which acres are you planting? And
to do that you gotta know how much water you got. And
... what happens is you sort of assume it's gonna be like
most years in the past and you're gonna have enough
water, and so you plant it, and then, you know, you could
get to June or July ... "Hey, you know, we got to shut off
for couple weeks." No, that doesn't work. So that was a
big deal for us ... For us, it's about stability here. You've
got just a tough ag economy and inability to know what
you've got with water just makes it that much worse.
(Interview, KWUA)

Lower Basin tribes were dissatisfied with the approach to water sharing associated with ESA compliance for a different reason. Rather than the minimum downstream flows required by NMFS, they wanted more variability in timing of flows to mimic the natural hydrologic regime, e.g., big spring pulses, in order to facilitate salmon recovery.

Our interviews revealed three important dynamics related to the Upper Basin/Lower Basin approach. First, the process featured little or no collaboration between BOR and the Services in the development of the proposed action. As a result, it led to a reactive approach that was inefficient and involved a lot of back and forth as the BOR tried to incorporate "real-time" consideration of the fishes' needs, based on recent data, into the proposed action over multiple meetings and drafts. Several times, the Services felt compelled to issue jeopardy opinions because BOR was not addressing the fishes' needs. Second, there was little or no coordination between FWS and NMFS in the development of their respective $\mathrm{BiOps}$ for $\mathrm{BOR}$, which resulted in a fragmented, single-species approach to ecosystem management. Third, the stakeholders' unanimous frustration with ESA implementation resulted in both fighting with each other and blaming the agencies for their problems. Furthermore, there were communication gaps resulting from lack of timely coordination among the agencies that led to reduced trust and any sense that local input had value.

Concurrent with growing agency recognition of the problems associated with Section 7 implementation was a period of media warfare following the tragic fish kill of 2002, which contributed to public perception of polarization in the basin. Adversaries were variously characterized as "tribes vs. irrigators," "Upper Basin vs. Lower Basin," and "federal agencies vs. local stakeholders." Around 2004, outside the scope of ongoing Section 7 consultation, leaders of basin tribes, irrigation groups, environmental and conservation NGOs, and federal agencies initiated a series of uncoordinated side meetings across the basin to discuss the potential for collaborative paths toward more integrated, basin-wide water and resource management (Gosnell and Kelly 2010). As side meetings became more coordinated and gained traction among a relatively representative group of stakeholder leaders in the basin, many of these leaders (on behalf of their constituent groups) intervened in the owner-initiated (PacifiCorp) Federal Energy Regulatory Commission (FERC) relicensing process for the Klamath Hydroelectric Project (KHP) around 2005. This process evolved into a venue to discuss water management problems across the entire basin, including the potential federal settlement of the Klamath Tribes' claims to unquantified water rights in the Upper Basin actively being sought by the state of Oregon in the Klamath Basin Water Adjudication Court. These discussions would eventually culminate in a series of agreements among stakeholders, the Klamath Basin Restoration Agreement (KBRA), and Klamath Basin Hydroelectric Settlement Agreement (KHSA), released to the public in 2010 and aimed at holistic basin restoration and water sharing (Gosnell and Kelly 2010, Chaffin et al. 2014a). These agreements required congressional authorization and funding and, after not receiving either, expired in 2016. However, the capacity built among stakeholders during the processes of negotiating these agreements also manifested in the development of the $2013 \mathrm{BiOp}$ and is arguably still latent in the basin, awaiting the next iteration of efforts to resolve water and associated natural resources conflict (Chaffin et al. 2016b).

A window of opportunity (Olsson et al. 2006) opened in 2010 when NMFS issued yet another jeopardy BiOp for the Lower Basin that conflicted with (and essentially negated) an earlier nonjeopardy BiOp issued by FWS for the Upper Basin (Table 1). Frustration came to a head over the lack of agency coordination in Section 7 implementation, and the need to identify a new, more coordinated approach became painfully apparent. The crisis resulted in resolve to pursue a joint $\mathrm{BiOp}$ emanating from both the Services' regional directors and from national leadership in Washington D.C. "The FWS was very unhappy with [the 2010 NMFS BiOp] because it didn't take into account the needs of the suckers upstream. There was dissatisfaction here in the basin ... and folks in D.C. did a lot of pushing" (Interview, FWS).

\section{DEVELOPMENT OF THE 2013 KLAMATH PROJECT JOINT BIOLOGICAL OPINION: AN SES APPROACH TO SECTION 7 CONSULTATION?}

To facilitate a more coordinated approach, regional directors for FWS, NMFS, and BOR met with their respective field office managers in November 2010 and directed them to develop a new 
proposed action and joint $\mathrm{BiOp}$. As one FWS employee observed, "we needed to come up with a proposed action that would work for everybody" (Interview, FWS). The goal was to take a more proactive and coordinated approach to developing a proposed action that would meet the conservation needs of the listed species while allowing continued operation of KIP in alignment with its authorized purposes and contractual obligations. Federal agency leaders established an Agency Coordination Team comprising biologists, hydrologists, managers, and support staff from each agency and, over the next 2 years, the Team met more than 25 times to develop what the agencies referred to as "a new paradigm and decision making process for managing [BOR]'s Project in a manner that provides more certainty for [KIP] water users, [UKL] elevations, and Klamath River flows than in the past" (NMFS and USFWS 2013:4).

A central goal of the new approach was to address the uncertainty and instability associated with past ESA implementation, which had, at different times over the previous decade, resulted in water shortages for irrigators, insufficient water for salmon in the Lower Basin, and insufficient lake levels for the suckers in the Upper Basin. Reducing uncertainty around water availability and timing for fish and farmers was a major motivator for collaboration, as described by this NMFS employee:

The tribal people want certainty. They want salmon runs to be robust and resilient and plentiful. The tribes also, of course, want more stability in their communities, you know, more stable fish runs, and more fish will provide them some of that. Stability and sustainability of their culture and their people. The water users in the Upper Basin ... they want certainty of water. What's really important is they know how much water ... they'll have access to. Delivered to them. Super important. (Interview, NMFS)

As such, the $2013 \mathrm{BiOp}$ was born of a new approach to annual water sharing that addressed the irrigators' needs, the suckers' needs, and the salmon's needs, exemplifying governmental capacity for flexibility and evolution within the constraints of formal law. It represented a fundamental shift from a single species approach to ESA implementation to an approach more reflective of systems thinking (although it still lacked consideration of private lands) that attempted to better acknowledge both the bioregion and the important role of the larger social context in developing solutions with legitimacy (Fig. 3). The capacity for this dramatic shift can partially be attributed to the general increase in communication, data sharing, and collaboration between basin stakeholders during the KBRA and KHSA negotiation period of roughly 2005-2010. As we discuss below, however, there were a few key aspects of the social dynamics of stakeholder relations in the basin that led to increased integration in the $2013 \mathrm{BiOp}$ and associated processes. Specifically, the $\mathrm{BiOp}$ featured new levels of integration in four dimensions: between the action agency and the Services in the development of the proposed action; between the Services in the development of the $\mathrm{BiOp}$; between biologists and hydrologists in seeking to better understand and manage the system; and among federal agencies and stakeholders in identifying innovative strategies for complying with the law that avoided putting all the risk on any one species or stakeholder.
Fig. 3. Section 7 Consultation Process for 2013 Joint Biological Opinion: Integrated Approach. Stakeholders collaborated on a water sharing plan using hydrologic modeling. Stakeholders shared data and information with Bureau of Reclamation (BOR) in development of proposed action (PA). BOR worked with National Marine Fisheries Service (NMFS) and U.S. Fish and Wildlife Service (FWS) to develop the PA in a coordinated way that took into account needs of fish. NMFS and FWS hired hydrologists to facilitate data and information sharing and improve communication about the conservation role of the action area in the survival and recovery of the listed species and in the recovery support function of critical habitat. NMFS and FWS issued a No Jeopardy Joint biological opinion (BiOp) that took into account needs of irrigators. Process featured collaborative, coordinated, integrated, proactive approach to development of PA and BiOp.

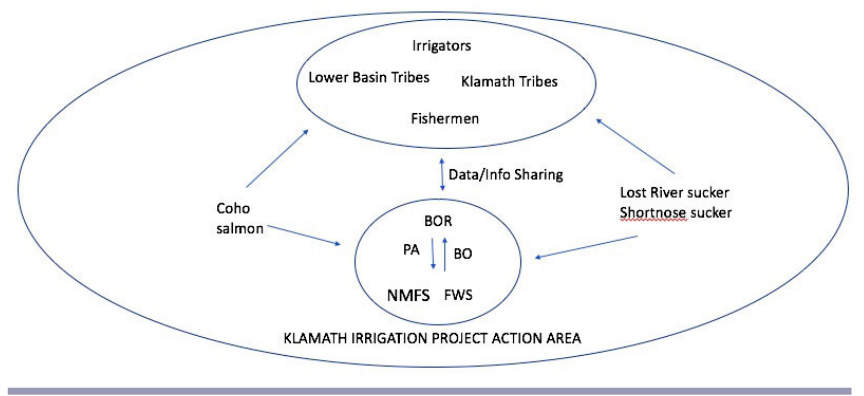

Shared responsibility for Section 7 compliance

In the past, BOR had always managed water resources in close collaboration with KIP water users. During the development of the joint $\mathrm{BiOp}$, the agency expanded its sphere of concern to include the Services and, by extension, the ESA-listed fish and the stakeholder groups advocating on their behalf, e.g., tribes and fishermen.

A key variable was a new regional director in the local BOR office who had "a whole different attitude towards Section 7 and working with [the Services], and the responsibility that BOR had to implement the ESA" (Interview, FWS). In a departure from the past, the new director convened a meeting of federal agency leaders and proposed a new approach involving setting allocations for KIP, the river, and UKL. As told by a FWS biologist, the new BOR director proposed,

... dividing up the pie three ways with the priority being for the lake and the river, and [KIP] would get whatever was left. And that was really another kind of "aha" moment. In the past, the way the proposed action was developed was BOR decided how much water [KIP] needed, or they just said we're going to operate as we had in the past. And then the fish are gonna get whatever is left over, and that was one of the reasons there was jeopardy, was because there was no certainty for the fish, and obviously the ESA does not allow all the risk to be put on the species. So when [the new BOR director] came, he kind of turned this around and asked [the Services], "OK, you tell us how much water you need and that's what we'll give you, and [KIP] will take whatever is left over." (Interview, FWS) 
This attitude represented a radical shift to the FWS biologists, who felt that BOR had been somewhat dismissive of its obligations under the ESA in the past and was now recognizing the importance of prioritizing the functionality and stability of the ecological system before trying to accommodate human use. It represented "a larger view that they, being part of the federal government, had responsibilities under Section 7 to consult, and consultation does not mean just delivering a BA [to the Services]" (Interview, FWS).

It is critical to note that BOR's attitude was made possible by the water users' interest in collaborating and their newfound willingness to make some concessions in exchange for more certainty, both of which were a result of increased trust associated with the KBRA discussions. As one water user recalled,

\begin{abstract}
We said, "Look, we'd be willing to trade some quantity of water, take less, in exchange for knowing early and having it be more stable, more secure." Cause even if you're short, if you know it at the beginning, you can manage, you can adjust. (Interview, KWUA)
\end{abstract}

Another important shift had to do with BOR-NMFS relations. While BOR and FWS had developed a good working relationship over the years as a result of being in the same U.S. Department (Interior) and both having offices in Klamath Falls (Oregon), the relations between BOR and NMFS, located in the U.S. Department of Commerce and housed "locally" in Arcata, California (several hundred miles away), were more strained. The new BOR director worked to actively engage NMFS staff to overcome the physical distance and institutional divide, inviting them, along with FWS, to help with the formulation of a proposed action that would meet the fishes' needs.

The new dynamic fostered a sense of shared responsibility among the three agencies for both the proposed action and the listed species, which led to a greater willingness to share data and compare notes and even include stakeholders in the process to the degree allowed by law. One FWS biologist observed that "having a longer period for the consultation and involving everybody" facilitated an improved problem-solving and trust-building approach.

\begin{abstract}
That really emphasized to me that that's the way consultations should work for these large projects. You need to take more time and be as open as you can with stakeholders. There has to be a shared responsibility among all the agencies [knowing that] the full process will be more successful if we're all working together than if we just try to use traditional tools like jeopardy and reasonable and prudent measures. (Interview, FWS)
\end{abstract}

The improved interagency dynamics (illustrated in Fig. 3), coupled with larger, basin-wide discussions among stakeholders (the constituents to which each agency is beholden) happening at the same time, facilitated a switch from a single species approach to a more integrated, SES approach characterized by a focus on relationships, processes, and feedbacks in the system rather than trying to control and optimize a single characteristic or property of the system, aligning the process in many ways with resilience theory (Benson 2012).

Critical to the success of the consultation process leading to the 2013 joint BiOp was a shared commitment among leaders in all three federal agencies to find a way to improve stability for water users while protecting the listed species. This approach stood in contrast to the "fish vs. farmers" framing of previous consultations. With the development of new social norms around agency interactions, there was less fear and uncertainty among the stakeholders, who felt more free to engage in creative problem solving involving the use of hydrologic modeling, which was critical to uncovering unexpected flexibility in the system.

\section{Hydrologic modeling: a tool to facilitate social and technical learning and systems thinking}

Most BiOps under the ESA are researched and written exclusively by biologists and ecologists from the Services. However, to better support the development of the 2013 Klamath joint BiOp, NMFS and FWS hired hydrologists to facilitate data and information sharing and to improve communication during the consultation process. The goal of these new hires was to help the agencies better understand a critical aspect of the ESA: the conservation role of the action area in the survival and recovery of the listed species and in the recovery support function of critical habitat.

It was very obvious to everybody that we needed a
hydrologist. We [the biologists] couldn't do it. If you
think about it, with all the biological uncertainty, and
then add to that hydrologic uncertainty, it's just toomuch.
There'snoway you can findany flexibility with that many
unknowns. (Interview, FWS)

The Services realized that they needed hydrologists not only to enhance communication, but also to be on more even footing with BOR hydrologists and to create space for authentic dialogue about where there might be flexibility in the system. The agency hydrologists were included in a technical team convened by the Klamath Tribes' hydrologist that represented the Lower Basin tribes, irrigators, and PacifiCorp, who owned the downstream dams. Stakeholders shared data and information with BOR, which worked with NMFS and FWS to develop the proposed action in a coordinated way that took into account needs of all listed fish. Relationship-building processes associated with KBRA negotiations were also critical in facilitating, inspiring, and catalyzing the collaborative modeling effort.

Two aspects of the modeling effort were transformational: the greater dependence on hydrologic science to better understand the system and eliminate power imbalances among the agencies, and the engagement of stakeholders in the modeling and learning about system function. By using hydrologic modeling to provide more certainty about what water they could possibly expect in the future, the agencies were able to take a more creative approach to problem solving. Focusing on the system (ecohydrology) rather than on a single species (biology) resulted in increased transparency about system limits, e.g., flows and water levels, which reduced tension and competitiveness among the agencies. Improved understanding of the system enabled improved congruence between rules and ecological conditions and improved "institutional fit" between the ESA and the basin SES (Olsson et al. 2006, Rijke et al. 2012). It also allowed the agencies to incorporate adaptive management into real-time KIP operations instead of trying to prescribe flows in the BiOp. In addition, the use of hydrologic modeling enhanced participants' ability to communicate and learn about system dynamics, resulting in a switch from a focus on optimizing water in different 
parts of the system for water users and individual species to a focus on fostering complexity, e.g., downstream pulses, and adaptive capacity (better predictions and ongoing opportunities for learning about the ecohydrology of the system).

Supporting the interagency consultation were side meetings among leaders of the Klamath Tribes, the Lower Basin tribes, and the irrigators about hydrologic modeling of the basin. These leaders had been meeting regularly to aid the developing collaborative approach to large-scale restoration of the entire basin associated with KBRA and KHSA, partially under the auspices of the ongoing FERC process to relicense (or remove) dams associated with the Klamath Hydroelectric Project (Gosnell and Kelly 2010, Chaffin and Gosnell 2017). As a result of these ongoing negotiations, stakeholders had already established an admittedly unusual degree of collaborative capacity and trust before getting involved in consultation for the joint $\mathrm{BiOp}$.

There were discussions that had already taken place, there were these coalitions that were building, there was just a lot more trust in the basin and less acrimony at least among the [KIP] water users and downstream tribes and Klamath Tribes. (Interview, FWS)

These side meetings helped advance a shared understanding of the basin's large, socially and geographically connected hydrology. We argue that this shared understanding of the system led to more acceptance of potential sharing of scarce water resources. According to a FWS participant in the consultation process,

\begin{abstract}
... the meetings were especially helpful for educating the Lower Basin tribes about the hydrology and how much water was really there that could be used for the river. And the water users were also at these meetings. So I think all these things had to work together ... you had to have the stakeholders' support, especially the Indian tribes, but also the water users. They had to agree to this whole new process of having more certainty about what they would get but less of a supply. And then the Indian tribes had to realize that there were limits on how much water could be available at certain times of the year. (Interview, FWS
\end{abstract}

The meetings had the dual purpose of promoting learning about the biophysical aspects of the system and its limits while also enhancing trust and communication, as the tribes and the water users were able to ask questions of the hydrologists and of each other. A FWS biologist summed this process up by observing that, "trust is established when the data gathering and analysis is done openly and cooperatively" (Interview, FWS).

The enhanced trust among the agencies and stakeholders meant that the biologists at NMFS and FWS had more flexibility to write the joint $\mathrm{BiOp}$ without fear of litigation.

Our attorneys played a very minor role in this BiOp compared to ones in the past. In past BiOps sometimes we were sitting down with the attorneys and writing these things together. The biologist would write something and the attorneys would look at it because they didn't want the BiOp to be vulnerable to a lawsuit by the water users or the tribes or the fishermen. In the past NMFS, FWS, and BOR each had an attorney involved in the whole process. It wasn't like that this time. There was still a concern about being arbitrary and capricious but there was less concern about being sued. So the attorneys really backed off. (Interview, FWS)

The reduced fear of litigation enabled a more creative approach to developing the $\mathrm{BiOp}$ that included risk taking not usually associated with the consultation process. A FWS biologist concluded that "minimizing the involvement of lawyers in the consultation process and writing of the $\mathrm{BiOp}$ improves creative problem solving, but is only possible in an atmosphere of trust."

Ultimately, NMFS and FWS issued a nonjeopardy joint BiOp that took into account the needs of both the fish and the irrigators. The BiOp authorized an operation model that is updated with water availability and use data each day, an approach that was expected to provide "close to real-time" data to enhance coordination between water elevations in UKL and Klamath River flows to be more reflective of natural variations, including occasional high flows for downstream salmon. As part of the process, NMFS had to come to terms with the fact that it could not prescribe high flows for a specific time; rather it had to devolve authority to local managers to allow high flows when possible based on real-time climatic conditions. We suggest that this concession to flexibility represented a transition toward incorporating adaptive capacity and the recognition of natural limits into real-time operation.

The collaborative modeling process facilitated transformative learning, leading participants to view the system in a more collective and holistic manner than they had before. This process, along with complimentary side-meetings among stakeholders, increased subsidiarity, tightened feedback loops for increased flexibility in water management response, and created more stability for water users. Sharing information led to more trust. The process was more integrated, with strengthened vertical and horizontal cross-scale linkages.

It is important to note that the $2013 \mathrm{BiOp}$, although unique in scope and approach, was not innovative enough in and of itself to foster lasting "peace" in the basin. After the expiration of the proposed KBRA and KHSA (without federal approval and funding, federal agencies could not participate in the terms of the agreement, which included KHP dam removal and basin-scale restoration activities), the FERC proceedings on the KHP dams were reinstated and the owner, PacifiCorp, came to an agreement with the Department of Interior for removal of four mainstem hydroelectric dams on the river (see Chaffin and Gosnell 2017). The planned dam removal represents just one aspect of the holistic approach to basin restoration proposed in the original KBRA and KHSA, and, in effect, negates other important aspects necessary for systemic change of water and associated species governance in the basin. In 2015 and 2016, conditions in the Lower Klamath River precipitated the spread of disease among returning coho salmon, causing high rates of mortality; under the $2013 \mathrm{BiOp}$, this two-year period should have triggered the BOR to reinitiate consultation with NMFS and FWS, but it did not. In late 2016, the Hoopa Valley Tribe (Lower Basin) filed suit to force BOR to reinitiate consultation; in February 2017, a judge from the U.S. District Court agreed (Table 1). 


\section{DISCUSSION: TAPPING THE POTENTIAL FOR ADAPTIVE GOVERNANCE}

In spite of recent events in the basin, we argue that the 2013 joint BiOp provides important lessons and insights into the role of law in adaptive governance. Cosens et al. (2017) note the current "dearth of legal mechanisms at any level that allow for alternatives to traditional environmental enforcement ... alternatives [that] could enhance local adaptive capacity while maintaining stability and accountability toward achieving the goals that traditional enforcement mechanisms seek to achieve." As the Klamath case suggests, this potential can be realized even in SES controversies with Section 7 at their core. The Klamath case provides insights into the ways in which law can evolve to make room for and even begin to institutionalize adaptive governance, in spite of periodic setbacks.

\section{Participatory capacity among stakeholders}

Although a main focus of this paper has been on the role of interagency relations, it is important to note that the impetus for change came from the stakeholders. Their determination to find an alternative approach to ESA implementation "trickled up" to influence, inspire, and motivate the agencies.

\begin{abstract}
The tribes and the water users were setting an example. It was hard for the agencies to ignore them. The agencies finally realized they needed to take advantage of that and emulate that. (Interview, FWS)
\end{abstract}

And I always kind of remind them, "You know the reason you are working together is because of us. It's not because of you guys, it's because we drug you together." We being us, the tribes, the key groups. And us doing that has made the agencies, their lives, a lot easier. (Interview, KWUA)

Over the course of the three-year consultation process that began in 2010, stakeholders and agency leaders began to see each other differently and developed new relationships, both personal and professional. Set against a backdrop of shifting tribal-irrigator power relations (Gosnell and Kelly 2010), some of these relationships had their origins in processes associated with the negotiation and support of the KBRA during the previous five years; nevertheless, the interactions associated specifically with the development of a joint $\mathrm{BiOp}$ added a new dimension because of the collective focus on understanding the biophysical system as a whole for the purpose of balancing stability and flexibility in KIP operations and avoiding jeopardy for listed species.

\section{Facilitating social and technical learning}

A key factor in the success of the consultation process leading to the 2013 joint $\mathrm{BiOp}$ was the ability to learn more about the system through data and information sharing and through hydrologic modeling, which allowed agency biologists and ecologists to see the system differently, shifting their focus from the life history of single species to the ecohydrology of the whole basin, an example of multiple loop learning (Armitage et al. 2008, Pahl-Wostl 2009). The collaborative approach to hydrologic modeling helped the agencies come to terms with inherent connectivity and uncertainty in the SES as they began to consider how water use and allocation in the system could be improved. The approach built on other learning experiences associated with KBRA negotiations that facilitated an expanded sense of place amongst stakeholders, who began to see the basin (and the effects of their water demand) in terms of a "whole" basin, not just isolated Upper and Lower Basins (Gosnell and Kelly 2010). Once the ecohydrologic system was better understood, stakeholders and government actors were empowered to improve "institutional fit" to better match the social and ecohydrologic dynamics.

We argue that ESA implementation without support for social and technical learning is incompatible with adaptive governance. Section 7 can be a trigger for social-ecological reorganization, adaptation, or transformation, but the right learning processes and forums must be present, otherwise Section 7 is more likely to act like a detonator than a stabilizer. As Rogers et al. (2013) note, "[d]eep reflection leading to transformational learning is required to foster the changes in mindset and behaviors needed to adopt a complexity frame of reference."

\section{Trust and empathic leadership in federal agencies and among stakeholders}

One aspect of the improved process in the Klamath Basin had to do with the attention the federal agencies gave to proactively negotiating and articulating a shared vision of the "desired state" for the SES (Chaffin et al. 2014b). In order to collaboratively develop an integrated joint $\mathrm{BiOp}$, agency leaders had to expand their historic spheres of responsibility and concern to include new elements. The BOR had to proactively incorporate the needs of the fish into its proposed action, and the Services had to develop a greater appreciation not only for "each other's fish" (both suckers and salmon) but also for the needs of the water users. There had to be a shared responsibility among the three federal agencies for BOR's proposed action as well as conservation of the listed species.

Although recognition of the important role that emotions played in Klamath Basin negotiations during the first decade of the 2000 s is nothing new (one has only to count the number of times locals teared up and talked about a "change in heart" when interviewed in the recent documentary film, A River Between Us, http://www. ariverbetweenus.com/), scholars interested in adaptive governance and SES transformation have yet to adequately theorize the important role played by these emotional geographies. Building on theories regarding the role of trust and social entrepreneurship in adaptive governance (Folke et al. 2005, Westley et al. 2011), this case reveals the importance of a culture of compassion and empathy for cultivating cross-scale interactions and a collective sense of stability, which created space for actors to deliberately transform institutions to support adaptive governance. Although the adaptive governance literature highlights the important role of social capital, including trust, collaboration, participatory capacity, leadership, social networks, and social learning (Folke et al. 2005), it focuses on the societal or group level of this phenomenon. It generally ignores the psychology of emotions, cognitive framing, empathy, and reconciliation in the creation and maintenance of social capital, which in turn supports society's adaptive capacity (e.g., Seyfarth and Cheney 2013, Arnold 2014). For example, strong leadership is central to the development of social capital and the adaptive capacity of governance systems, but the emotional aspects of leadership strategies have not been adequately acknowledged in the adaptive governance literature (Moore and Westley 2011, Evans et al. 2015).

In the Klamath case, a synergistic combination of leaders from different federal agencies and stakeholder groups came to a shared 
understanding that collaboration, humility, mutual respect, and empathy were necessary and desirable for progress to be made.

\begin{abstract}
Empathy is one of the things we need to be able to resolve this with, but dang, that's a tough thing. How do you get a rancher to know what it means to be a tribal person with that kind of history and that way of looking at the world? And how does the tribal person know the rancher's way of viewing the resource? Those kinds of things are very difficult. (Interview, Klamath Watershed Council)
\end{abstract}

Essential to the Klamath Basin social dynamics was the willingness and even desire to share limited water resources as well as information and data about the system. The willingness to share resulted from the cultivation of trust among federal agency leaders and the different groups of stakeholders. Such willingness was critical to the success of the joint BiOp because the expanded understanding of the system hinged on sharing of data and information that had not taken place in the past because of a siloed, fragmented approach to Section 7 implementation and distrust between agency scientists. The willingness to share water came from trust that reduced quantity of water would be compensated with greater certainty about amounts and better timing of adjustments.

The desire to share, however, was cultivated by the emergence of a culture of compassion and empathy among participants in the consultation process as well as the preceding KBRA process. In our interviews and in the popular media, stakeholders and federal agency leaders associated with water negotiations in the Klamath consistently reported experiencing an expanded sense of place and sphere of concern and empathy involving a "change in heart" for fish and people elsewhere in the basin that they had not previously considered. Several spoke of having been transformed or of transformative learning experiences that resulted in epiphanies about the basin's social and ecological dynamics and an expanded sense of concern, compassion, and empathy for people and species in other places.

Taken together, compassion and empathy are important precursors to what many adaptive governance scholars recognize as a crucial ingredient, trust. Participants in the consultation process leading to the 2013 joint $\mathrm{BiOp}$ trusted that even if environmental conditions changed and Section 7 consultation had to be reinitiated, the relationships they had forged and the collective culture of compassion and empathy would ensure that they would be treated fairly. Aside from any legal documentation, the core participants felt accountability to one another to ensure a legitimate, fair approach to sharing, even if resources became scarcer.

Although trust and empathy played an important role in enabling an integrated, collaborative approach, so too did nontribal stakeholders' fear of tribal power. It is important to note that at least part of the transformation reflected in the joint BiOp was the result of the failure of previous processes, including expensive lawsuits, to produce lasting beneficial results. Also, it was evident to some water users in the basin that the Klamath Tribes might apply their senior water rights in ways that could inhibit economically viable agriculture. This fear was realized in 2013 when the Klamath Tribes "called the river" ${ }^{[1]}$ for the first time after receiving legal quantification of water rights in the Klamath
Water Adjudication Court proceedings. The Tribes called on their water to be left instream for sucker habitat when low Upper Basin tributary flows occurred in June 2013. For the first time since Euro-American settlement of the basin, some Upper Basin farmers with land located upstream of the historical Klamath Tribes' reservation and upstream of the KIP had their water use reduced or curtailed. Some members of this stakeholder group had been among the most vocal opponents of the KBRA and KHSA, but they returned to the negotiating table in 2013-2014 after this call on their water rights by the Klamath Tribes (see Table 1; Upper Klamath Basin Comprehensive Agreement 2014).

\section{CONCLUSION: BUILDING FORUMS FOR ADAPTIVE GOVERNANCE}

In this article, we have sought to contribute to understanding of the role of law in adaptive governance by exploring the ways in which a seemingly rigid law like the ESA can be operationalized through an integrated problem solving approach and a focus on enhancing participatory capacity through forums for social and technical learning about a particular SES. The 2013 joint BiOp in the Klamath Basin was a historic first, in that it was the first time the two (often disparate) agencies entrusted with implementing the ESA came to a set of coordinated, place-based recommendations for conserving terrestrial and anadromous species at a basin-wide scale. The history of Section 7 implementation in the Klamath Basin provides an excellent case study of vastly different approaches to implementing the law.

The approach described herein both reflected and contributed to a fundamental change in the structure and function of the SES, and the resultant joint $\mathrm{BiOp}$ served to institutionalize this new trajectory to some degree, allowing it to gain power and legitimacy. In that sense, the Klamath case also provides insights into how institutionalization of emergent adaptive governance takes place. Although the good will engendered by the KBRA negotiations and the collaborative processes leading up to the 2013 joint BiOp may not be permanent, as recent events suggest, we argue that stronger interagency relationships built on trust and a mutual understanding of SES dynamics, specifically the ecohydrology of the basin, provide a new baseline capacity for integrated problem solving in the future. We argue that the joint $\mathrm{BiOp}$ represents at least a partial social transformation involving change in behavior, procedures, customs, norms, values, and beliefs that altered environmental governance in the basin.

In closing, we emphasize that the value of the Klamath case is not so much that it provides evidence that Section 7 need not be contentious; rather, we see it as providing lessons for legal programs managing SESs more broadly, e.g., Section 404 permitting under the Clean Water Act, environmental assessments under the National Environmental Policy Act, and water planning, forest planning, and land use planning more generally. These lessons include identifying leaders who can creatively avoid entrenched silos and facilitate interagency collaboration, take a proactive approach that involves affected parties in early stages of problem solving, and provide opportunities for collaborative social and technical learning to enhance SES understanding. The Klamath case also suggests the need for more serious exploration of the role of empathy and emotional geographies more generally in SES functioning and the need for further investigation into the benefits and challenges of 
interagency collaboration involving interdisciplinary considerations of whole systems, e.g., the ways in which different species and both biotic and abiotic factors interact with one another. Such holistic, integrated approaches to governing water resource allocation will become more important as water scarcity related to climate change continues to threaten both biodiversity and agricultural livelihoods.

Responses to this article can be read online at: http://www.ecologyandsociety.org/issues/responses. $\mathrm{php} / 9887$

\section{Acknowledgments:}

This work was developed as part of the Adaptive Water Governance Project, funded by the National Socio-Environmental Synthesis Center (SESYNC) under funding from the National Science Foundation, NSF DBI-1052875. The authors would like to thank Barbara Cosens and Ron Larson for their valuable insights and feedback, which strengthened the article, along with Klamath Basin stakeholders who agreed to be interviewed. We also thank Anna Crockett for cartographic support and design.

\section{LITERATURE CITED}

Armitage, D., M. Marschke, and R. Plummer. 2008. Adaptive comanagement and the paradox of learning. Global Environmental Change 18(1):86-98. http://dx.doi.org/10.1016/j.gloenvcha.2007.07.002

Arnold, C. A. 2004. Working out an environmental ethic: anniversary lessons from Mono Lake. Wyoming Law Review $4: 1-55$.

Arnold, C. A. 2014. Framing watersheds. Pages 271-302 in K. H. Hirokawa, editor. Environmental law and contrasting ideas of nature: a constructivist approach. Cambridge University Press, Boston, Massachusetts, USA. http://dx.doi.org/10.1017/ CBO9781139519762.015

Arnold, C. A. 2015. Environmental law, episode IV: a new hope? Can environmental law adapt for resilient communities and ecosystems? Journal of Environmental and Sustainability Law 21 (1):1-46.

Arnold, C. A., O. O. Green, D. A. DeCaro, A. Chase, and J. G. Ewa. 2014. The social-ecological resilience of an eastern urbansuburban watershed: the Anacostia River Basin. Idaho Law Review 51:29-90.

Benson, M. H. 2012. Intelligent tinkering: the Endangered Species Act and resilience. Ecology and Society 17(4):28. http://dx.doi. org/10.5751/ES-05116-170428

California Department of Fish and Game (CDFG). 2004. September 2002 Klamath River fish-kill: final analysis of contributing factors and impacts. Northern California-North Coast Region, The Resources Agency, State of California, USA. [online] URL: http://waterwatch.org/wp-content/ uploads/2011/08/2002CAFinalKlamathFishKillReport.pdf

Carpenter, S. R., and W. A. Brock. 2008. Adaptive capacity and traps. Ecology and Society 13(2):40. http://dx.doi.org/10.5751/ ES-02716-130240
Chaffin, B. C., R. K. Craig, and H. Gosnell. 2014a. Resilience, adaptation and transformation in the Klamath River Basin socialecological system. Idaho Law Review 51:157-194.

Chaffin, B. C., A. S. Garmestani, H. Gosnell, and R. K. Craig. 2016a. Institutional networks and adaptive water governance in the Klamath River Basin, USA. Environmental Science \& Policy 57:112-121. http://dx.doi.org/10.1016/j.envsci.2015.11.008

Chaffin, B. C., A. S. Garmestani, L. H. Gunderson, M. H. Benson, D. G. Angeler, C. A. (T.) Arnold, B. Cosens, R. K. Craig, J. B. Ruhl, and C. R. Allen. 2016b. Transformative environmental governance. Annual Review of Environment and Resources 41:399-423. http://dx.doi.org/10.1146/annurev-environ-110615-085817

Chaffin, B. C., and H. Gosnell. 2017. Beyond mandatory fishways: federal hydropower relicensing as a window of opportunity for dam removal and adaptive governance of riverine landscapes in the United States. Water Alternatives 10 (3):819-839.

Chaffin, B. C., H. Gosnell, and B. A. Cosens. 2014b. A decade of adaptive governance scholarship: synthesis and future directions. Ecology and Society 19(3):56. http://dx.doi.org/10.5751/ ES-06824-190356

Chapin III, F. S., G. P. Kofinas, and C. Folke, editors. 2009. Principles of ecosystem stewardship: resilience-based natural resource management in a changing world. Springer-Verlag, New York, New York, USA.

Cosens, B. A., R. K. Craig, S. Hirsch, C. A. (T.) Arnold, M. H. Benson, D. A. DeCaro, A. S. Garmestani, H. Gosnell, J. Ruhl, and E. Schlager. 2017. The role of law in adaptive governance. Ecology and Society 22(1):30. http://dx.doi.org/10.5751/ ES-08731-220130

Craig, R. K. 2014. Does the Endangered Species Act preempt state water law? University of Kansas Law Review 62:851.

Craig, R. K., A. S. Garmestani, C. Allen, C. A. Arnold, H. Birge, D. DeCaro, A. Fremier, H. Gosnell, and E. Schlager. 2017. Balancing stability and flexibility in adaptive governance: an analysis of tools available in U.S. environmental law. Ecology and Society 22(2):3. http://dx.doi.org/10.5751/ES-08983-220203

DeCaro, D. A., C. A. (T.) Arnold, E. F. Boamah, and A. S. Garmestani. 2017. Understanding and applying principles of social cognition and decision making in adaptive environmental governance. Ecology and Society 22(1):33. http://dx.doi. org/10.5751/ES-09154-220133

Doremus, H., and A. D. Tarlock. 2008. Water war in the Klamath Basin: macho law, combat biology, and dirty politics. Island Press, Washington, D.C., USA

duToit, D., and S. Pollard. 2008. Updating public participation in IWRM: a proposal for a focused and structured engagement with Catchment Management Strategies. Water SA (6):707-713.

Evans, L. S., C. C. Hicks, P. J. Cohen, P. Case, M. Prideaux, and D. J. Mills. 2015. Understanding leadership in the environmental sciences. Ecology and Society 20(1):50. http://dx.doi.org/10.5751/ ES-07268-200150

Folke, C. 2006. Resilience: the emergence of a perspective for social-ecological systems analyses. Global Environmental Change 16(3):253-267. http://dx.doi.org/10.1016/j.gloenvcha.2006.04.002 
Folke, C., F. S. Chapin III, and P. Olsson. 2009. Transformations in ecosystem stewardship. Pages 103-128 in F. S. Chapin, G. P. Kofinas, and C. Folke, editors. Principles of ecosystem stewardship: resilience-based natural resource management in a changing world. Springer-Verlag, New York, New York, USA. http://dx.doi.org/10.1007/978-0-387-73033-2_5

Folke, C., T. Hahn, P. Olsson, and J. Norberg. 2005. Adaptive governance of social-ecological systems. Annual Review of Environmental Resources 30:441-473. http://dx.doi.org/10.1146/ annurev.energy.30.050504.144511

Foster, S. 2002. Environmental justice in an age of devolved collaboration. Harvard Environmental Law Review 26:459-498.

Gosnell, H. 2001. Section 7 of the Endangered Species Act and the art of compromise: the evolution of a reasonable and prudent alternative for the Animas-La Plata Project. Natural Resources Journal 41(3):561-626.

Gosnell, H., and E. Kelly. 2010. Peace on the river? Socialecological restoration and large dam removal in the Klamath Basin, USA. Water Alternatives 3(2):361-383.

Grantham, H. S., M. Bode, E. McDonald-Madden, E. T. Game, A. T. Knight, and H. P. Possingham. 2010. Effective conservation planning requires learning and adaptation. Frontiers in Ecology and the Environment 8:431-437. http://dx.doi.org/10.1890/080151

Gunderson, L. H. 2013. How the Endangered Species Act promotes unintelligent, misplaced tinkering. Ecology and Society 18(1):12. http://dx.doi.org/10.5751/ES-05601-180112

Gunderson, L. H., A. S. Garmestani, K. W. Rizzardi, J. B. Ruhl, and A. Light. 2014. Escaping a rigidity trap: governance and adaptive capacity to climate change in the Everglades socialecological system. Idaho Law Review 51:127.

Holling, C. S. 2001. Understanding the complexity of economic, ecological, and social systems. Ecosystems 4(5):390-405. http:// dx.doi.org/10.1007/s10021-001-0101-5

Huitema, D., E. Mostert, W. Egas, S. Moellenkamp, C. PahlWostl, and R. Yalcin. 2009. Adaptive water governance: assessing the institutional prescriptions of adaptive (co-) management from a governance perspective and defining a research agenda. Ecology and Society 14(1):26. http://dx.doi.org/10.5751/ES-02827-140126

Jaeger, W. K. 2004. Conflicts over water in the Upper Klamath Basin and the potential role for market-based allocations. Journal of Agriculture and Resource Economics 29(2):167-184.

Karkkainen, B. C. 2008. Getting to "let's talk": legal and natural destabilizations and the future of regional collaboration. Nevada Law Journal 8:811-829.

Larson, K. L., and D. Lach. 2010. Equity in urban water governance through participatory, place-based approaches. Natural Resources Journal 50:407-430.

Moore, M.-L., O. Tjornbo, E. Enfors, C. Knapp, J. Hodbod, J. A. Baggio, A. Norström, P. Olsson, and D. Biggs. 2014. Studying the complexity of change: toward an analytical framework for understanding deliberate social-ecological transformations. Ecology and Society 19(4):54. http://dx.doi.org/10.5751/ ES-06966-190454
Moore, M.-L., and F. Westley. 2011. Surmountable chasms: networks and social innovation for resilient systems. Ecology and Society 16(1):5. http://dx.doi.org/10.5751/ES-03812-160105

National Marine Fisheries Service and U.S. Fish and Wildlife Service (NMFS and USFWS). 2013. Biological opinions on the effects of proposed Klamath Project operations from May 31, 2013, through March 31, 2023, on five federally listed threatened and endangered species. National Marine Fisheries Service, Southwest Region, Northern California Office and U.S. Fish and Wildlife Service, Klamath Falls Fish and Wildlife Office, Oregon, USA.

National Research Council (NRC). 2002. Scientific evaluation of biological opinions on endangered and threatened fishes in the Klamath River Basin: Interim Report. National Academy Press, Washington, D.C., USA.

National Research Council (NRC). 2004. Endangered and threatened fishes in the Klamath River Basin: causes of decline and strategies for recovery. National Academies Press, Washington D. C., USA.

Olsson, P., L. H. Gunderson, S. R. Carpenter, P. Ryan, L. Lebel, C. Folke, and C. S. Holling. 2006. Shooting the rapids: navigating transitions to adaptive governance of social-ecological systems. Ecology and Society 11(1):18. http://dx.doi.org/10.5751/ ES-01595-110118

Pahl-Wostl, C. 2009. A conceptual framework for analysing adaptive capacity and multi-level learning processes in resource governance regimes. Global Environmental Change 19:354-365. http://dx.doi.org/10.1016/j.gloenvcha.2009.06.001

Pahl-Wostl, C., G. Becker, C. Kneiper, and J. Sendzimir. 2013. How multilevel societal learning processes facilitate transformative change: a comparative case study analysis on flood management. Ecology and Society 18(4):58. http://dx.doi.org/10.5751/ ES-05779-180458

Prokopy, L. S., N. Mullendore, K. Brasier, and K. Floress. 2014. A typology of catalyst events for collaborative watershed management in the United States. Society \& Natural Resources 27 (11):1177-1191. http://dx.doi.org/10.1080/08941920.2014.918230

Quick, K. S., and M. S. Feldman. 2011. Distinguishing participation and inclusion. Journal of Planning Education and Research 31(3):272-290. http://dx.doi.org/10.1177/0739456X11410979

Rijke, J., R. Brown, C. Zevenbergen, R. Ashley, M. Farrelly, P. Morison, and S. van Herk. 2012. Fit-for-purpose governance: a framework to make adaptive governance operational. Environmental Science \& Policy 22:73-84. http://dx.doi. org/10.1016/j.envsci.2012.06.010

Rogers, K. H., R. Luton, H. Biggs, R. Biggs, S. Blignaut, A. G. Choles, C. G. Palmer, and P. Tangwe. 2013. Fostering complexity thinking in action research for change in social-ecological systems. Ecology and Society 18(2):31. http://dx.doi.org/10.5751/ ES-05330-180231

Ruhl, J. B. 2012. The Endangered Species Act's fall from grace in the Supreme Court. Harvard Environmental Law Review 36:487. http://dx.doi.org/10.2139/ssrn.1953339

Saundry, P. 2009. Endangered Species Act, United States. The Encyclopedia of Earth. [online] URL: http://www.eoearth.org/ view/article/152413/ 
Sax, J. L., and R. B. Keiter. 2006. The realities of regional resource management: Glacier National Park and its neighbors revisited. Ecology Law Quarterly 33:233.

Seyfarth, R. M., and D. L. Cheney. 2013. Affiliation, empathy, and the origins of theory of mind. Proceedings of the National Academy of Sciences 110 (Supplement 2):10349-10356. http://dx. doi.org/10.1073/pnas. 1301223110

Shilling, F. M., J. K. London, and R. S. Liévanos. 2009. Marginalization by collaboration: environmental justice as a third party in and beyond CALFED. Environmental Science and Policy 12:694-709. http://dx.doi.org/10.1016/j.envsci.2009.03.003

U.S. Department of the Interior. 2010. Klamath Basin Restoration Agreement for the sustainability of public and trust resources and affected communities. U.S. Department of the Interior, Washington, D.C., USA. [online] URL: http://klamathrestoration. gov/sites/klamathrestoration.gov/files/Klamath-Agreements/KlamathBasin-Restoration-Agreement-2-18-10signed.pdf

U.S. Fish and Wildlife Service and National Marine Fisheries Service (USFWS and NMFS). 1998. Endangered Species Act consultation handbook: procedures for conducting Section 7 consultations and conferences. U.S. Fish and Wildlife Service, Washington, D.C., USA.

Westley, F., P. Olsson, C. Folke, T. Homer-Dixon, H. Vredenburg, D. Loorbach, J. Thompson, M. Nilsson, E. Lambin, J. Sendzimir, B. Banerjee, V. Galaz, and S. van der Leeuw. 2011. Tipping toward sustainability: emerging pathways of transformation. AMBIO: A Journal of the Human Environment 40(7):762-778 http://dx.doi. org/10.1007/s13280-011-0186-9 